\title{
Архитектор Фридрих Ларс (1880-1964) и его литографии «Город Канта. 8 изображений Кёнигсберга 18 века». Часть 2
}

\author{
И.В.Белинцева, НИИТИАГ, Москва
}

Восемь литографических городских пейзажей города Кёнигсберга XVIII века (совр. Калининград, РФ) были выполнены в 1936 году архитектором Ф. Ларсом для торжественного выступления на ежегодном праздновании дня рождения философа Иммануила Канта (1724-1804)1 . Доклад - «бобовую речь», произнесённую в 1936 году, Ф. Ларс начал словами: «со времён Канта Кёнигсберг так изменился, что каждый, кто знает город в его теперешнем виде, едва ли сумеет сделать правильное представление о городе XVIII века»² [1]. Следует отметить, что с момента выступления Ф. Ларса облик города претерпел радикальные перемены: были утрачены ключевые исторические объекты, изменились многие городские районы. Тем более важно реконструировать историческую среду, в которой обитал знаменитый философ, не считая нужным выезжать за пределы родной провинции. Здесь он черпал бессмертные идеи о границах познания и роли человеческого разума, которого «осаждают вопросы, от которых он не может уклониться» [2, с. 9].

Прибывающих в Кёнигсберг издавна встречал Зелёный мост (Грюне брюке) - один из семи кёнигсбергских мостов, через рукав реки Прегель (Старую Преголю) (рис. 1). Деревянное сооружение над рекой, соединявшее островную часть города с предместьем (Форштадт), было впервые упомянуто в 1322 году [3, с. 18]. Историк К. Фабер писал, что мост назывался первоначально «Ланггассенбрюке» (мост Длинного переулка) [4, S. 19]. В 1582 году он сгорел, его восстановили спустя шесть лет уже под названием Зелёный мост. В 1907 году деревянный переход заменили разводным металлическим мостом с ручным механизмом, а разобрали в 1972 году при строительстве существующего эстакадного моста над островом Канта (бывш. Кнайпхоф).

За мостом располагались Зелёные ворота, ведущие в южную часть острова Кнайпхоф, который представлял собой третий по счёту город (после Альтштадта и Лёбенихте), вошедший в 1724 году в структуру объединённого Кёнигсберга. «0н назывался Прегельмюнде или Нойштадт, однако верх взяло старопрусское наименование Книпав в своей онемеченной форме - Кнайпхоф. Центральной осью равномерной уличной сети являлась улица Кнайпхофская Ланггассе» [3, с. 19]. Несмотря на естественную преграду в виде реки, в Средние века остров окружала каменная стена, в которой из четырёх крепостных проездов выделялись главные въездные ворота Грюнес Тор, «красивейшие во всем городе, визитная карточка, которой Кёнигсберг встречал приезжающих» [3, с. 19].

Ворота выходили на кнайпхофскую Длинную улицу, где «дома сплошные, староманерные, превысокие, этажей в пять и в шесть, и чрезвычайно узкие, а единая ширина и прямизна придаёт ей наилучшую красу, - писал будущий известный российский писатель, мемуарист, учёный и паркостроитель А.Т. Болотов (1738-1833), попавший в город во время Семилетней войны (1756-1763), будучи совсем молодым человеком, $-<\ldots>$ не мог довольно налюбоваться красотою и пышностью многих улиц, а особливо так называемой Кнайпхофской большой улицей, которую наши тотчас окрестили по-своему и назвали Миллионною, потому что вся она была не только прямая, но состояла из наилучших и богатейших домов в городе» [5, с. 27].

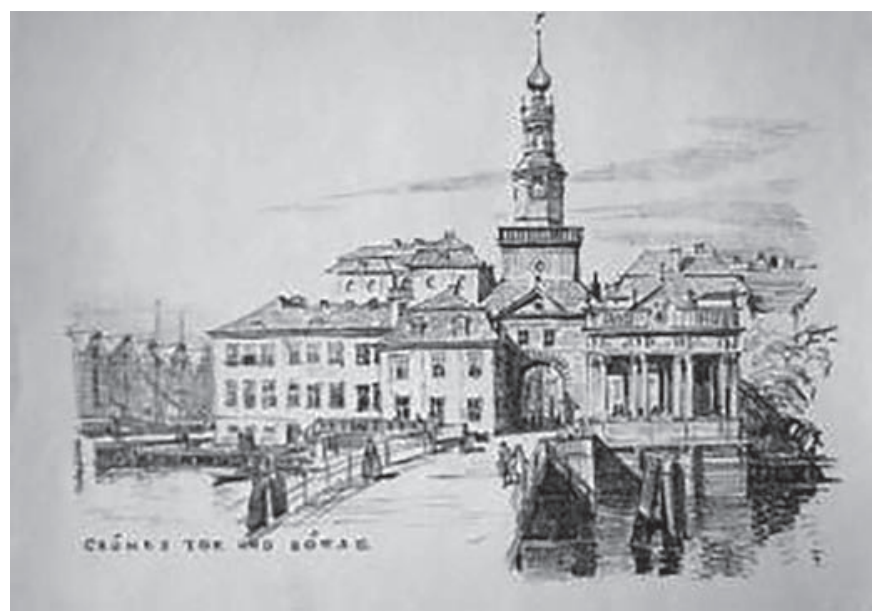

Рис. 1. Фридрих Ларс. Зелёные ворота и биржа (источник: Калининград, ММО, ед. хранения № 5361636)

\footnotetext{
*) Продолжение. Часть 1 статьи «Архитектор Фридрих Ларс (1880-1964) и его литографии “Город Канта. 8 изображений Кёнигсберга 18 века"» опубликована в № 3 журнала «Аcademia. Архитектура и строительство» за 2020 год.

**) Исследование выполнено за счёт средств Государственной программы Российской Федерации «Развитие науки и технологий» на 2013-2020 годы» в рамках Плана фундаментальных научных исследований Минстроя России и РААСН, тема 1.2.23.

1 Полный комплект литографий хранится в Музее Мирового океана (ММ0, Калининград). Автор благодарит руководство Музея Мирового океана за предоставленную возможность их опубликовать.

2 Перевод цитаты - И. Белинцева. Полный перевод литературной части речи на русский язык сделан С. Колбанёвой и опубликован на сайте «0бщества друзей Канта и Кёнигсберга» в августе 2020 г. (https://freunde-kants.wixsite.com/freunde-kants-ru/bohnenrede-lahrs-rus).
} 
На плане Георга Брауна (1550) Зелёные ворота имеют вид мощного укреплённого проезда с единственной полуциркульной сквозной аркой, над которой возвышались ярусы меньшего объёма, завершённые двускатной кровлей ${ }^{3}$ (рис. 2). На гравюрах Иоахима Беринга (1613) и Маттеуса Мериана (1641) Зелёные ворота имеют вид более представительного башнеобразного сооружения, завершённого куполом и витой шишкой (рис. 3). Восьмигранная ступенчатая ярусная башня над средневековым четырёхгранным основанием была выстроена в конце XVI века возможно по проекту голландских мастеров, много работавших в это время на побережье Балтики. В её облике использована излюбленная и широко применяемая голландскими архитекторами конструкция, тип которой распространился на Руси, начиная с петровского времени, и получил название «восьмерик на четверике». Сооружение снесли в 1864 году при расширении Длинной улицы Кнайпхофа, однако сохранились живописные и графические изображения, даже фотографии [6].

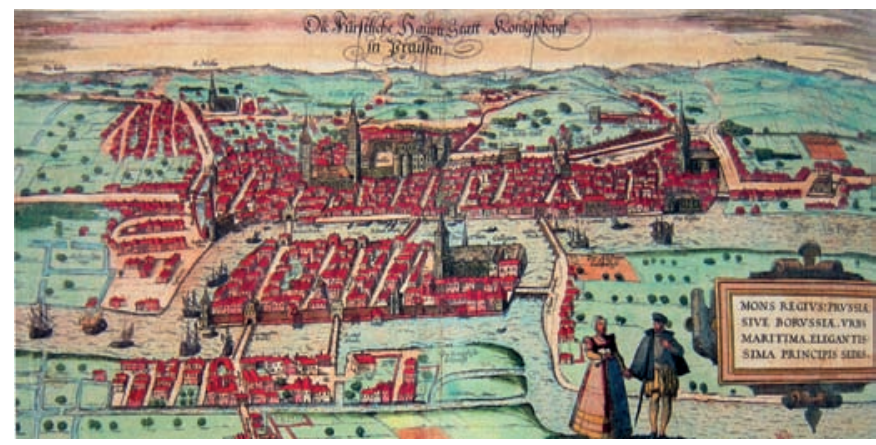

Pис. 2. Георг Браун и Франс Хогенберг. Кёнигсберг с высоты птичьего полёта. Гравюра на меди. 1581 год (источник:[21])

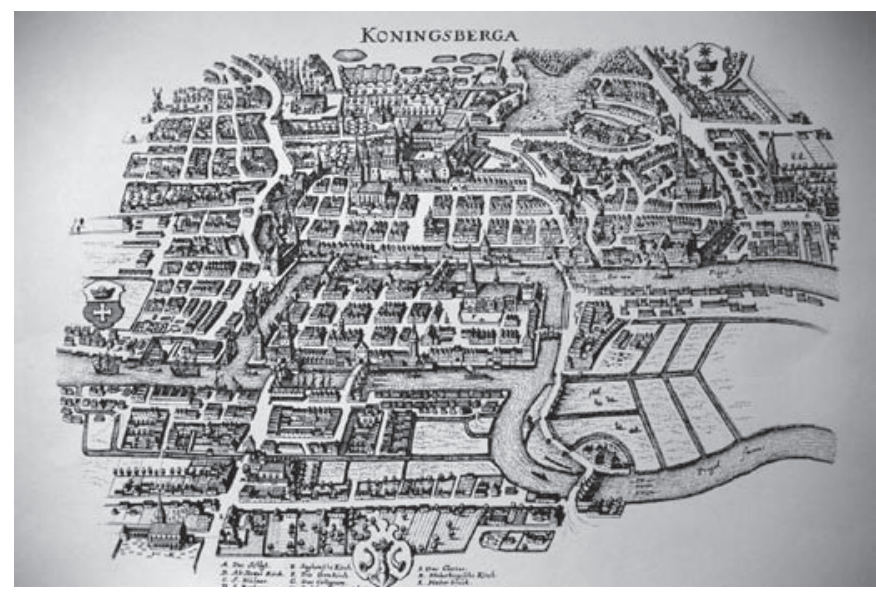

Pис. 3. Маттеус Мериан. Кёнигсберг с высоты птичьего полёта. Гравюра. 1641 год (источник: [10])
Ф. Ларс чётко прорисовывает детали Зелёных ворот - массивный объём нижней части с проездом, обрамлённым рустом, этаж для сторожей, увенчанный классическим фронтоном. Хорошо видна обходная галерея четверика второго яруса, над которым возвышается высокий восьмерик с круглым циферблатом часов, далее заметен сквозной ярус с колонками. Наверху на фоне неба прорисована луковичная главка с флагштоком.

Справа от внешнего въезда и Зелёного моста бросается в глаза стоящее над рекой здание на сваях - торговая биржа. Известно, что «в Кёнигсберг регулярно прибывали верховые вестовые, купцы собирались в том месте, где в город въезжал конный почтальон - у ворот Грюнес Top, - чтобы взять у него свою корреспонденцию. Это место было удобным и для заключения сделок. Поэтому решили построить для этого специальное здание. Так как оно должно было служить всем купцам, его нельзя было построить на земле города Кнайпхофа. Выход нашли, построив здание над Прегелем, принадлежавшем не городу, а удельному князю. Биржа простояла на этом месте до 1875 года» 4 [3, с. 95]. На гравюре М. Мериана (1641) представлено небольшое сооружение, построенное на манер городских домов, характерных для побережья Балтики: одноэтажное сооружение перекрыто двумя крутыми двускатными крышами, щипцы которых обращены к реке. Астроном, математик и путешественник, представитель известного семейства учёных Бернулли, Иоганн Бернулли III (1744-1807) в 1778 году так описал здание: «К общественным сооружениям принадлежит построенная на реке Прегель купеческая биржа, которая, благодаря своему расположению, не имеет подобных в Европе. 0на была заново построена в 1624 году и украшена многочисленными статуями; потолок украшали 58 искусно нарисованных аллегорических картин, содержание которых нельзя понять, кроме нескольких при них имеющихся и нечитабельных более стихов; они нарисованы... голландцем Грегором Зингкнехтом» [7, S. 86]. Русский консул И.Л. Исаков упоминал в реляции 1785 года о «купеческой бирже, построенной на сваях над самым Прегелем возле мосту, называющемся Гринебрике» [8, с. 629].

Здание биржи неоднократно перестраивалось, очередной основательный ремонт был предпринят в 1729 году, и, видимо, в этом виде здание существовало на протяжении жизни И. Канта (рис. 4). Используя в качестве образца гравюру 1834 года, архитектор Ф. Ларс изобразил лёгкое и просторное классицистическое многоколонное здание с крышей, закрытой аттиком и небольшим фронтоном по центру фасада.

${ }^{3}$ «Так называемый «план Брауна» (der Braunsche Plan) - первый известный план города Кёнигсберга (вид города около 1550 года); гравюра неизвестного автора, напечатанная Георгиусом Брауном в третьем томе [под названием «Urbium praecipuarum totiusmundiliber tertius» («3наменитых городов всего мира книга третья»)] своего пятитомного латинского издания «Civitates orbis terrarium» («Города земного шара»), вышедшего в Кёльне в 1576-1606 годы; немецкое издание книги под названием «Beschreibung und Contrafaktur der vornembster Stät der Welt» вышло в свет в 1574-1618 годы [3, с. 94].

${ }^{4}$ В 1875 году на противоположном берегу реки было построено новое здание Биржи (архитектор Генрих Мюллер, Бремен). 
Историк К. Фабер отметил, что «в 1800 г. была построена новая биржа, как и прежняя, на сваях над Прегелем»5. Он описывает здание довольно подробно: «Фахверковая биржа обшита досками, снаружи стены были 80 фус ${ }^{6}$ длиной и 44 фус ширины, покрыта высокой деревянной крышей из толстых досок. Фронтоны двух передних сторон покоятся на ионических колоннах и образуют портики глубиной 10 фус. Длинные стороны имеют двойной ряд окон. Обращённая к форштадту украшена маленьким фронтоном, на котором размещены резные гербы трёх городов. Главный вход находится на Зелёном мосту. Современная окраска имеет красноватый цвет камня» $[4, \mathrm{~S} .88]$.

Новая биржа была представлена на многочисленных изображениях XIX века. На рисунке гуашью (1810, художник В. Барт) здание прорисовано особенно наглядно: с позднеклассическими деталями - спаренными ионическими колоннами

${ }^{5}$ Исследователи называют также дату - 1798 г. [23, S. 56].

${ }^{6}$ Фус - немецкая мера длины, около 0,30 м.

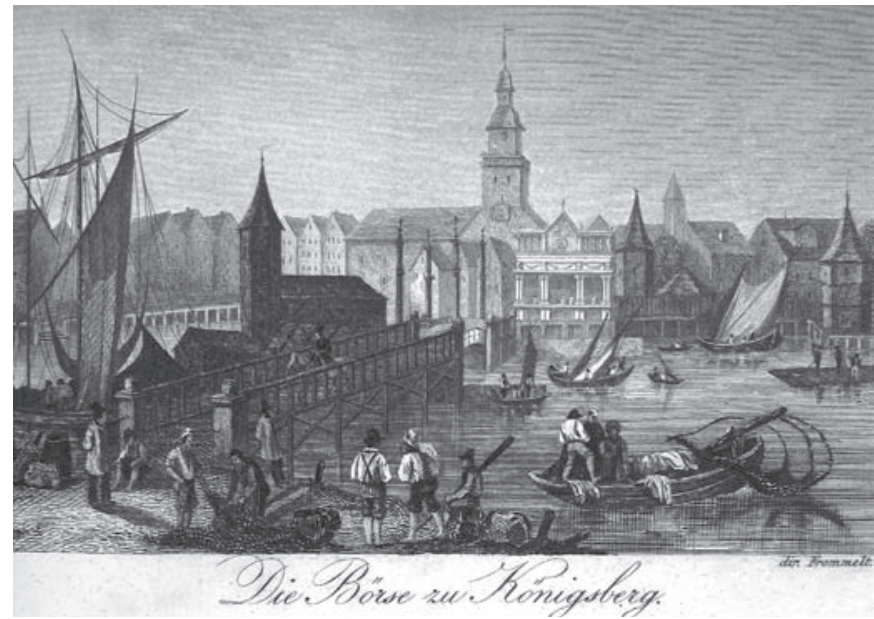

Puс. 4. Фроммен. Кёнигсберг. Биржа и Зелёный мост. Гравюра. 1834 год (источник: [21])

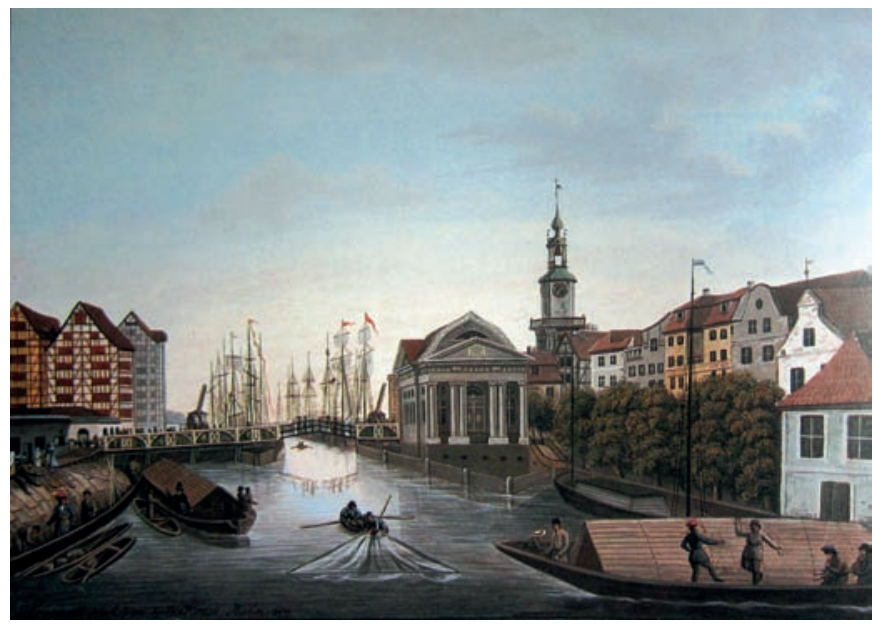

Рис. 5. Вильгельм Барт. Вид на биржу с противоположного берега. Гуашь. Гуашь. 1810 год (источник: [10]) на высоких постаментах, рельефами фронтона и антаблемента (рис. 5). На гравюре Х. Э. Раушке (1780 - после 1835) «Пожар в Кёнигсберге 14 июня 1811 г.» биржа предстаёт в виде массивного здания, высота которого достигает середины восьмерика соседних Зелёных ворот. Она перекрыта сводчатой двускатной крышей и украшена портиками с фронтонами по всей ширине фасадов. На этой гравюре хорошо заметна узкая улочка, отделяющая биржу от застройки Кнайпхофа (рис. 6).

Литография Ф. Ларса «Гавань и Красный кран» передаёт вид, открывающийся с левого берега реки Прегель, со стороны бывшей улицы Кранштрассе, тянувшейся от Зелёного моста к крепости Фридрихсбург (рис. 7). Здесь на южном берегу реки располагались складские постройки (ластадии), принадлежавшие жителям Кнайпхофа. С правой стороны, в глубине рисунка, далёким миражом возвышаются башни замка и церковь Старого города. Слева открывается вид на район амбаров, принадлежавший Альтштадту. А. Болотов описывает ужаснувшую его территорию амбаров, где его поселили во время Семилетней войны: «Глухие и никем не обитаемые узкие

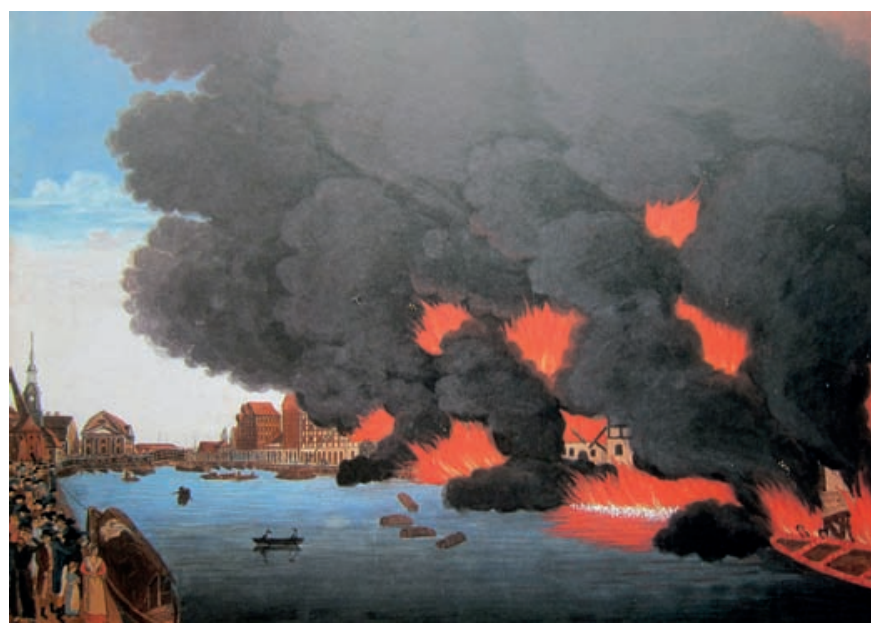

Рис. 6. Раушке. Пожар в Кёнигсберге 14 июня 1811 г. Цветная гравюра (источник: [10])

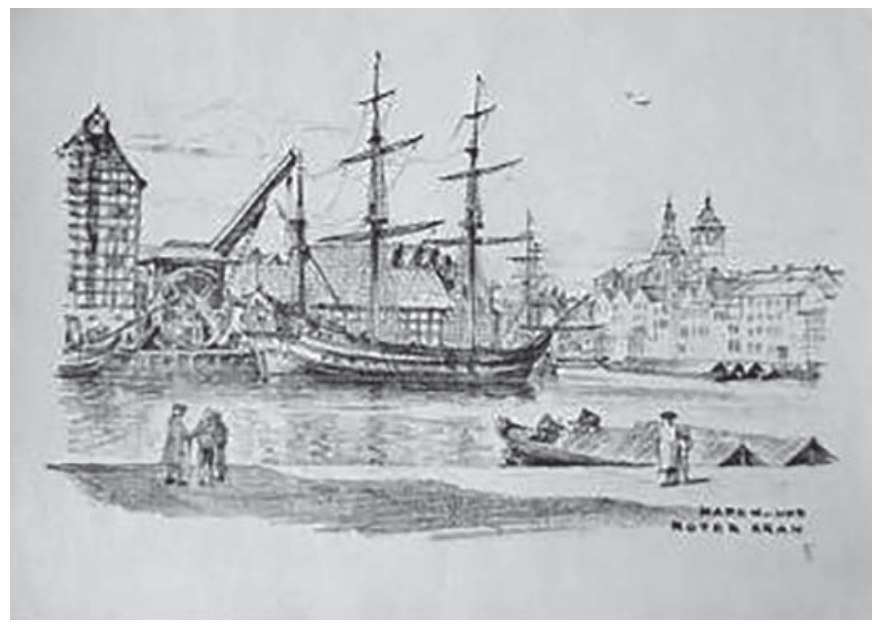

Рис. 7. Фридрих Ларс. Гавань и Красный кран (источник: Калининград, ММО, ед. хранения № 5361653) 
переулки, находящиеся между так называемыми шпиклерами, или огромной величины хлебными амбарами, для которых в городе отведён особый глухой и от лучших городских мест удалённый угол или квартал, и где построено их было несколько сот вместе и сплошь один подле другого, и каждый таковой амбар составлял предлинное, но при том чрезвычайно узкое и этажей семь вверх простирающееся самое простое, грубое полукаменное здание...» [5, с. 25].

«На ластадиях находились краны для загрузки и разгрузки судов и для снятия и монтажа мачт, городские весы, ниже по течению судоверфи, склады для хранения золы, извести, смолы, а также другие хранилища; кроме того, площадки для хранения леса, на которых складировался строительный лес и дрова» [3, S. 22].

Ф. Ларс запечатлел большой кран и пришвартованное парусное судно перед фахверковыми амбарами. Кран представлял собой подобие высокой будки с длинной стрелой, которая управлялась с помощью огромного вертикально поставленного колеса. Русский консул И.Л. Исаков в «0пи-

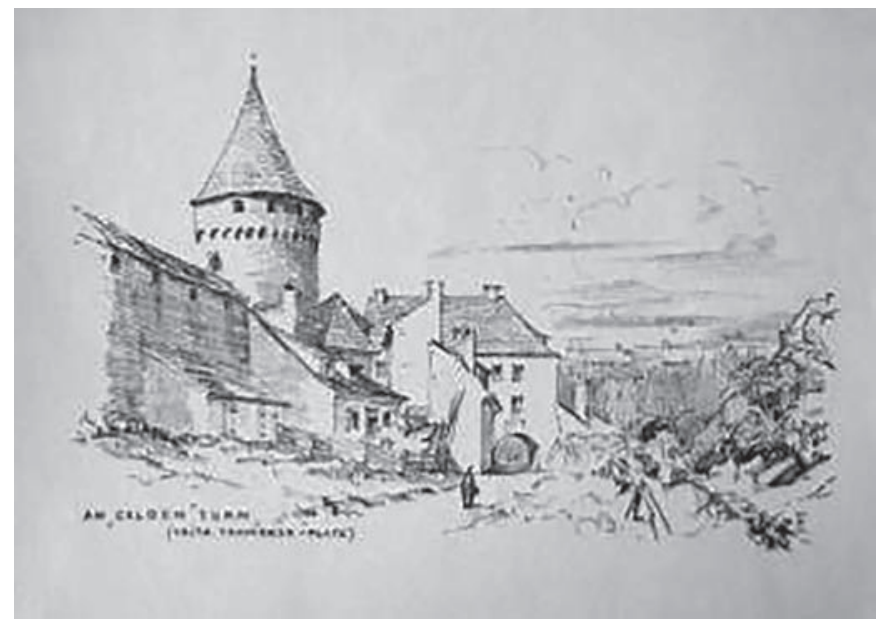

Рис. 8. Фридрих Ларс. У Жёлтой башни (площадь Фрица Чирзе) (источник: Калининград, ММО, ед. хранения № 5361655)

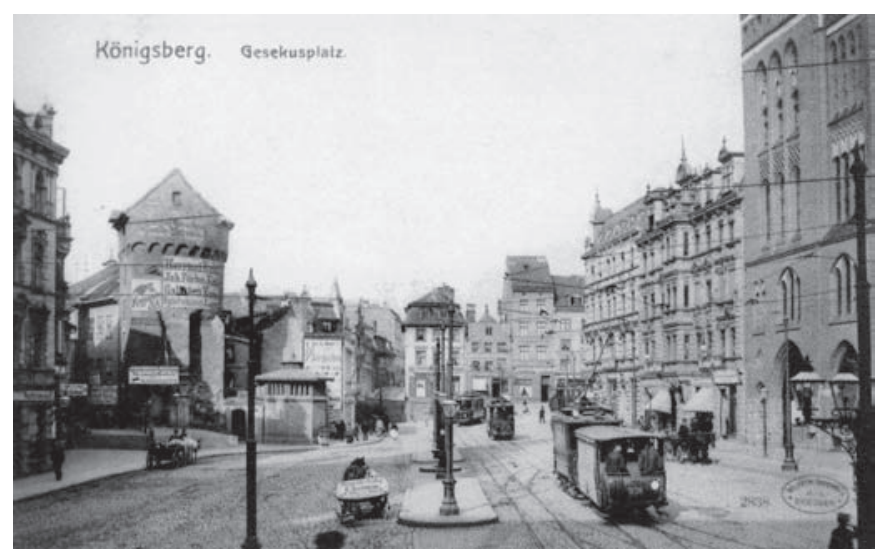

Рис. 9. Кёнигсберг. Жёлтая башня и Гезекусплац. Открытка начала XX века (источник: [22]) сании Кёнигсберга» (1785) отметил, что на реке Прегель к альтштадской и кнайпхофской складским сторонам «принадлежат два крана или подъёмныя машины, которыми тягости подымаются» [8, с. 629]. Важность подъёмных механизмов была значительна: так, крану была посвящена одна из многочисленных картин, размещённых в интерьере торговой биржи в 1624 году (художник Грегер Зингкнехт) и обновлённых в 1729 году (художник Иоганн Фридрих Байер). В честь крана были написаны поясняющие вирши (автор - университетский профессор красноречия (амуэль Фухс), опубликованные в 1731 году: «Кран, благодаря которому выгружают товары из кораблей. При нем стоят поляк, голландец, англичанин и немец, которые торгуют друг с другом. Нужда объединяет людей и соединяет их...» [4, S. 86].

На литографии «У Жёлтой башни (площадь Фрица Чирзе)» архитектор изобразил улицу, ведущую вдоль внешних оборонительных стен Альтштадта (Старого города)", по которой бредёт одинокая женская фигура с корзиной в руках (рис. 8). Старый город был окружён со всех сторон каменными крепостными стенами, построенными в 1333-1350 годах. «Стена была в среднем двухметровой ширины и девятиметровой высоты, нижняя часть её была выложена из валунов, верхняя, где была проложена оборонительная галерея, из кирпича... Из всех ворот и башен Альтштадта сохранилась лишь «Жёлтая» башня, - писал историк города Фриц Гаузе [3, S. 15]. Она служила в средневековье арсеналом, а позднее использовалась в качестве тюрьмы. В 1796 году было предложено снести Жёлтую башню, «однако городской строительный мастер Бликк вынес заключение о нецелесообразности сноса. Магистрат принял решение: «Пустая башня должна остаться для сохранения статус-кво» [9, с. 74], и здание осталось одиноко стоять после разборки в 1800 году прилегающих стен ${ }^{8}$ [10, S. 110]. «B 1800 году из соседней - Воровской - башни - в Жёлтую были переведены восемь пленных - и городской советник Хампус пенял магистрату на то, что в Жёлтой башне отсутствует жилье для сторожей и потому использовать её как тюрьму недопустимо» [9, с. 74]. После сноса в 1860-е годы ветхой застройки перед западным крылом замка возле башни появилась большая рыночная площадь, названная в 1882 году Гезекусплац (площадь Гезекуса ${ }^{9}$ ), переименованная в начале $1930-$ годов $^{10}$ (рис. 9).

«Хранитель древностей» Восточной Пруссии А. Бёттихер (1842-1901) писал в 1897 году о «ещё стоящей Жёлтой башне,

${ }^{7}$ Альтштадт назывался с 1265 года Кёнигсбергом, но после появления рядом Лёбенихте или Нового города, а затем Нового города Кнайпхофа, пришлось обозначить каждый город отдельным именем [4, S. 86].

${ }^{8}$ Крепостная башня простояла вплоть до середины 1950-х годов.

9 Гезекус Иоганн Хайнрих, комиссар юстиции, в 1802 году завещал Кёнигсбергу значительное состояние в размере 74000 талеров с весьма своевольными и эксцентричными условиями их использования [9, S. 124].

${ }^{10}$ Гезекусплац располагалась в начале улицы Штайндамм (ныне ул. Житомирская). В 1930-е годы получила имя Фрица Чирзе, нацистского деятеля СС и СА. Сейчас на этом месте стоит Дом Связи (Ленинский проспект). 
квадратной внизу, с полукруглой стеной, обращённой вовне, расположенной на четвёртом ярусе; шестой ярус с арочным пояском; поверху башня имела выступающий вперёд обход с зубцами и конусовидной крышей вместо теперешней, её исказившей» $[11$, S. 176]. Он не упоминает о происхождении названия башни. Известно, что определение «жёлтая» появилось намного позже самой башни: «в 1864 году её купил предприниматель Герман Кадах и прикрепил на неё гигантский рекламный щит ядовито-жёлтого цвета» [9, с. 74].

На литографии Ф. Ларс представил реконструкцию верхней части башни, но без обхода с зубцами, существование которых Ф. Ларс отрицал, считая выдумкой Хенше, описавшего сооружение в 1872 году [1]. Впрочем, зубцы могли появиться в середине XIX века в связи с увлечением английской готикой, когда в Восточной Пруссии массово украшали старые и вновь построенные башни подобными признаками средневековья.

На литографии Ф. Ларса «Бастионы возле Голландского шлагбаума» изображён обширный пейзаж с низким горизонтом, позволяющий раскрыть широкую панораму реки и земляных укреплений, начатых в 1624 году (рис. 10). Строительство валов велось за счёт городской казны и средств курфюрста, и тянулось почти до конца XVII столетия ${ }^{11}$. Крепостные сооружения представляли собой обвалование протяжённостью 15 километров, с восемью воротами, 26-ю полными бастионами и восемью полубастионами, расположенными в месте пересечения валов с рукавами Старой и Новой Преголи. На многочисленных картах последующего времени план Кёнигсберга представлен в виде почти правильного круга с фигурными звездчатыми выступами (рис. 11). Земляные укрепления города создавались в нидерландской манере, особенностью которой было сочетание низких валов и широких рвов, что связано с близостью почвенных вод к поверхности земли на родине укреплений - в Нидерландах.

Изображая панораму города с едва заметными защитными валами, потерявшими уже в XVIII веке оборонительное значение (см. рис. 10), Ф. Ларс использовал типичный для него приём диагональной композиции, уводящей взгляд в далёкую перспективу. На переднем плане на пологом берегу реки Ф. Ларс располагает две небольшие человеческие фигурки: сидящая указывает рукой за пределы видимости зрителя, а у стоящей фигуры в руках подзорная труба, направленная вдаль. По характерному, отчётливо выделенному на светлом фоне силуэту в плаще и шляпе узнаётся изображение И. Канта.

Слева представлена высокая ветряная мельница голландского типа - с подвижной верхней надстройкой и решетчатыми крыльями, перед которой стоит едва заметная повозка с запряжённой лошадью. В Восточной Пруссии существовали

${ }^{11}$ Проект валовых сооружений создал профессор математики, ученик Кеплера, преподаватель архитектуры и астрономии университета в Кёнигсберге Иоганн Штраус. Руководил строительными работами генерал граф Абрахам фон Дона. Техническое руководство осуществлял личный архитектор бранденбургского курфюрста Конрад фон Борке [12, S. 17].

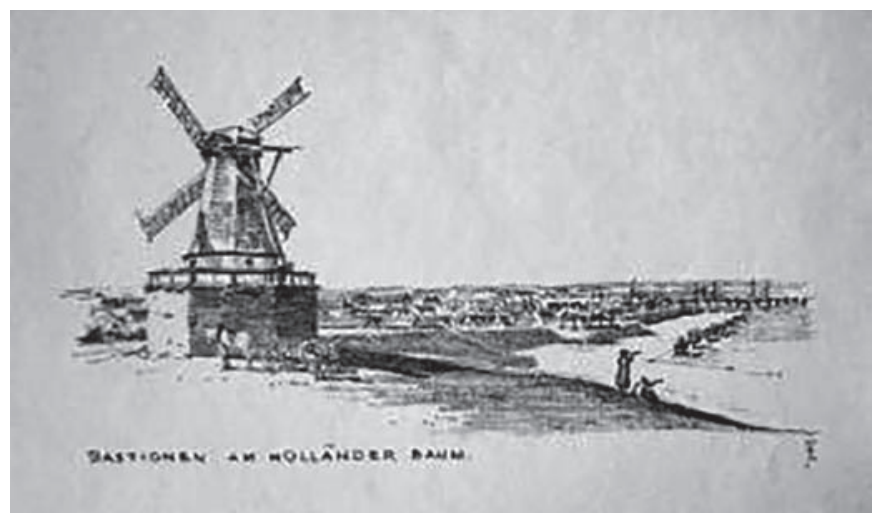

Рис. 10. Фридрих Ларс «Бастионы возле Голландского шлагбаума» (источник: Калининград, ММО, ед. хранения № 5361589).

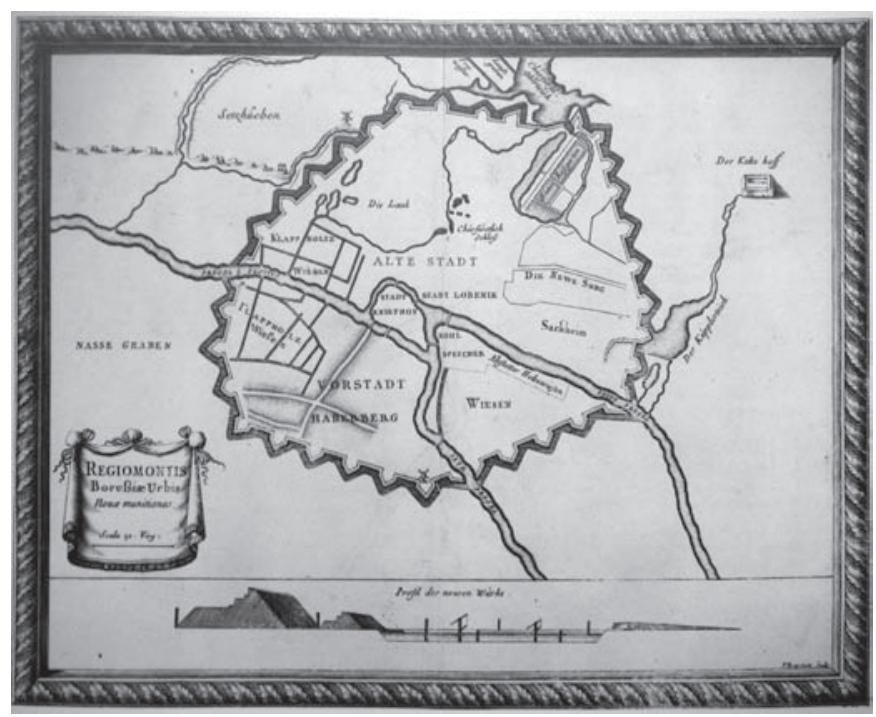

a)

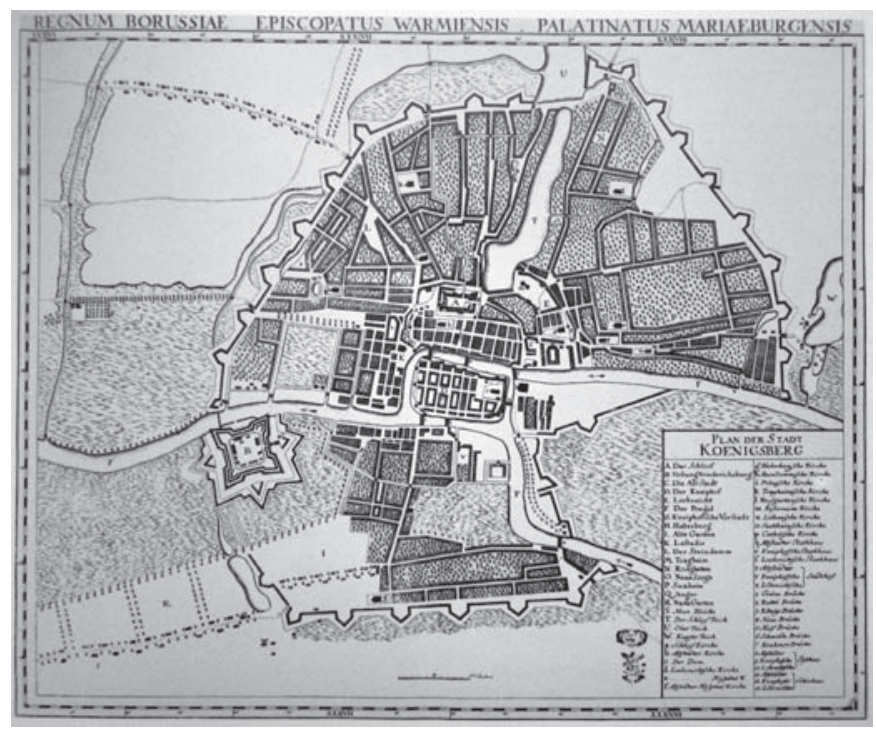

б)

Рис. 11. План Кёнигсберга (источник [10]): а) Ф. де Лапунт. Кёнигсберг. Барочные укрепления. 1696 год; б) план Прусской академии наук. Около 1765 года 
различные типы водяных и ветряных мельниц: «кроме мукомольных и лесопильных мельниц имелись также шлифовальная и полировальная мастерские, в которой чистильщики лат или мастера по изготовлению пластин полировали латы; мельница для дубления, используемая сапожниками и дубильщиками; пороховая мельница, мельница по выработке солода и, может быть, маслобойня» [3, с. 22]. Их ставили обычно далеко за пределами города, чтобы избавить горожан от лишнего шума и неприятных запахов.

Территория городского пропускного пункта Холлендербаум - Голландского шлагбаума, была расположена на правом берегу реки Прегель, там, где земляные валы почти вплотную подходили к реке. Название появилось благодаря многочисленным голландским кораблям, бросавшим здесь якорь. Два новых шлагбаума - Голландский и Литовский, появились в ходе строительства укреплений XVII века. Русский консул И.Л. Исаков писал в реляции 1785 года, что «на реке Прегель находятся два запора, называемыя: 1. Голлендишер-баум, сей для приходящих и отходящих в море кораблей. 2. Литаушербаум, сей для прибывающих рекою из нутренности малых судов и барок» [8, с. 629]. Историк Ф. Гаузе пояснял, что «они не только запирали на ночь реку, но служили важной составной частью таможенной границы, возведённой вокруг города управлением курфюрста. По отношению к кораблям и плотам охранники шлагбаумов имели примерно такие же обязанности, какие были у учётчиков, стоявших у ворот города, по отношению к повозкам и саням» [3, с. 99].

На литографии Ф. Ларса под названием «Сад коммерческого советника Сатургуса на Новых рвах. Сейчас - Цшокский приют» воспроизведена центральная часть садового фасада городской усадьбы богатого кёнигсбергского купца Фридриха Сатургуса (1696-1754), построенной в стиле рококо приблизительно в 1752-1754 годы (архитектор не установлен). Перед дворцом изображён партер обширного сада с широкой аллеей, обрамлённой цветниками и садовыми скульптурами, по которой прогуливаются персонажи в костюмах XVIII века. Как и на других литографиях «бобовой речи», персонажи изображены со спины, зритель словно заглядывает тайком в давно ушедшую жизнь. Этот эффект усилен боковыми кулисами в виде разросшихся деревьев и кустарниками переднего плана, отделяющих сцену в парке от праздных соглядатаев (рис. 12 а). В основу литографии Ф. Ларса положена старинная фотография, в композицию которой внесены небольшие изменения для придания большей жизненности и «дыхания старины» (рис. 12 б). Автор несколько изменяет силуэт парковой скульптуры слева, которая на фотографии имеет невыразительный облик, на более эффектную женскую фигуру в ниспадающих пышных драпировках. Правую статую мастер оставляет почти без изменения. Место цветущего дерева с фотографии заняла статуарная фигура, поднятая на постамент.

Сады и парки занимали особое место в истории Кёнигсберга [13]. Писатель и историк Н. Карамзин писал в 1789 году о Кёнигсберге: «Здесь есть изрядные сады, где можно с удовольствием прогуливаться. В больших городах весьма нужны народные гульбища. Ремесленник, художник, учёный отдыхает на чистом воздухе по окончании своей работы, не имея нужды идти за город. К тому же испарения садов освежают и чистят воздух, который в больших городах всегда бывает наполнен гнилыми частицами» [14, с.104].

Самый знаменитый сад эпохи рококо XVIII века в Кёнигсберге, который почитали своим долгом посетить высокопоставленные гости города, появился по инициативе купца, коммерческого советника Фридриха Сатургуса, успешного торговца, служившего поставщиком вин при прусских королях, поддерживавших позднее и его наследников [15, S. 100].

Семейство Сатургусов относилось к богатейшим жителям Восточной Пруссии наряду с горожанами из рода Шерре, Негеляйн, Фаренхайд [16, S. 561]. Основоположник семейства, торговец рейнскими винами Адольф Сатургус, приехавший

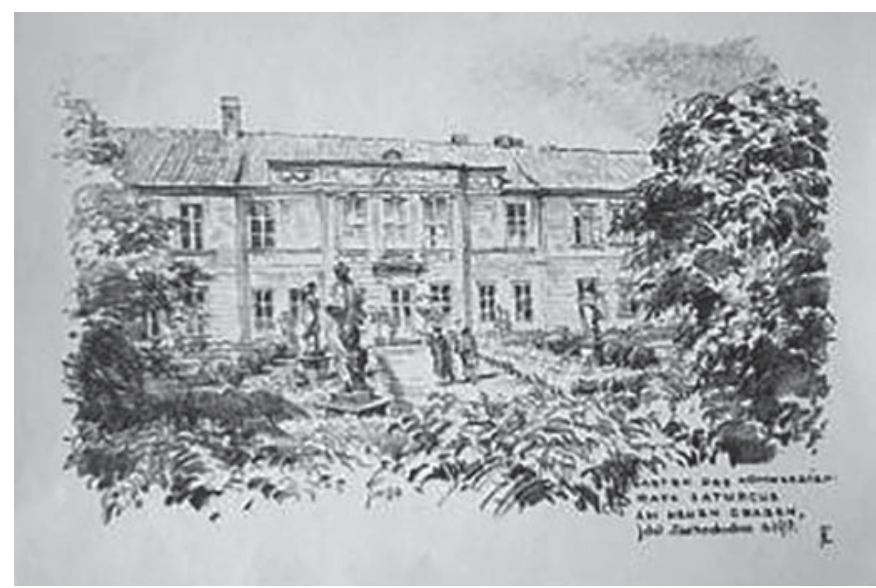

a)

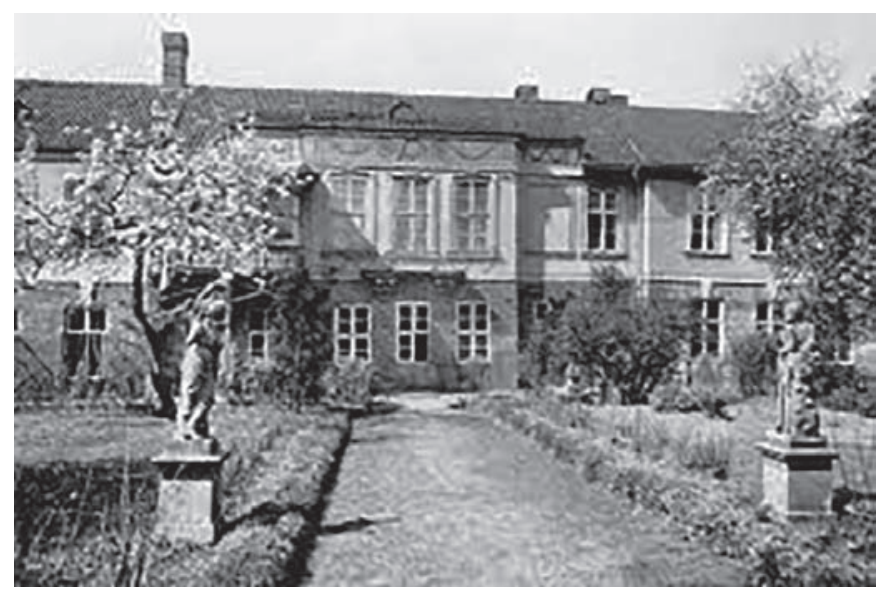

б)

Рис. 12. а) Фридрих Ларс. Сад коммерческого советника Сатургуса на Новых рвах. Сейчас - Цшокский приют (источник: Калининград, ММО, ед. хранения № 5361601); б) старинное фото, положенное в основу литографии Ф. Ларса (фото из открытых источников сети Интернета) 
в Кёнигсберг из Дюссельдорфа, стал в 1681 году гражданином Кнайпхофа [16, S. 661; 15, S. 96]. Богатая вдова купца, умершего в 1700 году, Анна Элизабет Сатургус (1664-1746) купила в 1722 году у наследников купца Даниэля Баумгартена большой участок с домом, садом и конюшнями в районе Ластадия, на территории, называемой Новые рвы (Нойер Грабен, сейчас - территория между улицами Мариупольской и Красноярской $)^{12}$.

Ф. Сатургус унаследовал от матери купленную землю, постепенно увеличивая её размеры. Эта земля перед городскими укреплениями в середине XVIII века была практически свободной от застройки, отсюда открывался широкий обзор почти до морской гавани. Купец построил здесь дворец и создал единственный в Восточной Пруссии парк в стиле рококо, заложенный в 1753 году на месте основанного ещё в начале столетия старинного регулярного сада. Ф. Сатургус приложил немало усилий для обустройства необычного парка - с многочисленными затеями, причудливо обстриженными деревьями, шпалерами, фонтанами, оранжереями, зверинцем, кунсткамерой и т.д.

Завершением работы над парком было выполнение предписания магистрата Кёнигсберга о создании аллеи, идущей вокруг обширного владения коммерческого советника. Владелец парка должен был на собственные средства замостить дорогу, замкнуть обход двумя нарядными воротами и обсадить аллею липами, предоставив её в распоряжение горожан. «Летом 1753 г. все было готово. Волшебный сад был наполнен проточной водой, липовые аллеи, ещё молодые, предлагали уютные тенистые места для отдыха, сделанные из песчаника путти приветствовали со своих постаментов, рокайльные фонтаны радовали посетителей, как главный экспонат сверкал ракушечный грот. К сожалению, неизвестно, один или несколько садовников работали у Сатургуса» [15, S. 101]. Ф. Сатургус не успел вполне насладиться своим садом - он умер весной 1754 года в возрасте 57 лет.

Парк вызвал восторг у двадцатилетнего А. Болотова. Он писал, что из городских районов ни один «так не достопамятен, как тот, на котором находится сад одного наибогатейшего купца Сатургуса. Сад сей хотя и не очень обширен, но почесться может наилучшим во всем Кёнигсберге, ибо он не только расположен регулярно, но и украшен всеми возможнейшими украшениями. Хозяин, будучи любопытный учёный и богатый человек, наполнил оный многими редкими вещами... Есть также тут множество разными фигурами обстриженных деревьев, а площади все украшены множеством изрядных фонтанов. Вода для сих фонтанов втягивается насосами из канала, подле сада находящегося, в большой свинцовый бассейн, сокрытый в построенной нарочно для сего на углу сада прекрасной башне, внизу которой сделана

12 Цшокский приют был полностью разрушен во время англо-американских налётов 1944 года. Тогда же выгорел весь усадебный комплекс, в настоящее время полностью застроенный. изрядная беседка и в ней колокольная игра, производимая той же водой» [5, с. 56].

Одной из достопримечательностей парка был грот, расположенный напротив садового фасада дворца. По мнению немецких исследователей Л. Гольдштейна [17, S. 165] и Х. М. Мюльпфордта [15, S. 99], грот представлял собой уникальное явление не только в Восточной Пруссии, но и на северо-востоке Европы (рис. 13). Первым грот подробно описал кёнигсбергский поэт Иоганн Фридрих Лоусон (1727-1783), сочинявший вирши «на случай», постоянным заказчиком стихотворений которого был Ф. Сатургус. Прозванный «поэтом воды», Ф. Лоусон с восторгом восхвалял причудливые водные потоки и многочисленные изваяния человеческих и фантастических фигур, украшавшие грот. Он писал, что выложенные из камня, раковин, улиток и цветных камней мозаичные персонажи многократно отражались в зеркалах, складываясь в причудливые фигуры. В двух углах интерьера стояли божества, которые механически двигали руками и головой, вращали глазами и языками. Из настоящих раковин были выложены лики чудовищ, вокруг которых стояли четыре путти. Корона из ракушек брызгала водой и т.д. «Весь грот был неописуемо прекрасен..., кто его не видел, не поверит поэту» $[15$, S. 103]. В 1930-х годах грот был обновлён под руководством скульптора Ф. Трайне $[19, \text { S. 247 }]^{13}$.

Разбогатевшие на торговле с Россией наследники купца, его племянники Фридрих Франц (1728-1810) и Адольф Бартоломеус (1730-1803) Сатургусы продолжали украшать усадьбу, устраивать блестящие праздники, концерты, театральные представления. «11 июля 1776 г. у них обедал великий князь Павел, будущий царь, и брат короля принц Генрих. Купцы в красной униформе и расшитых золотом жилетах стояли в почётном карауле. Весь сад был иллюминирован, и Сатургус произнёс трогательную речь. Праздник был очень успешным, особенно русские гости нашли его превзошедшими все их

13 Грот простоял в неизменном виде 190 лет (за исключением утрат в результате пожара 1803 года), до бомбового налёта англо-американской авиации в августе 1944 года.
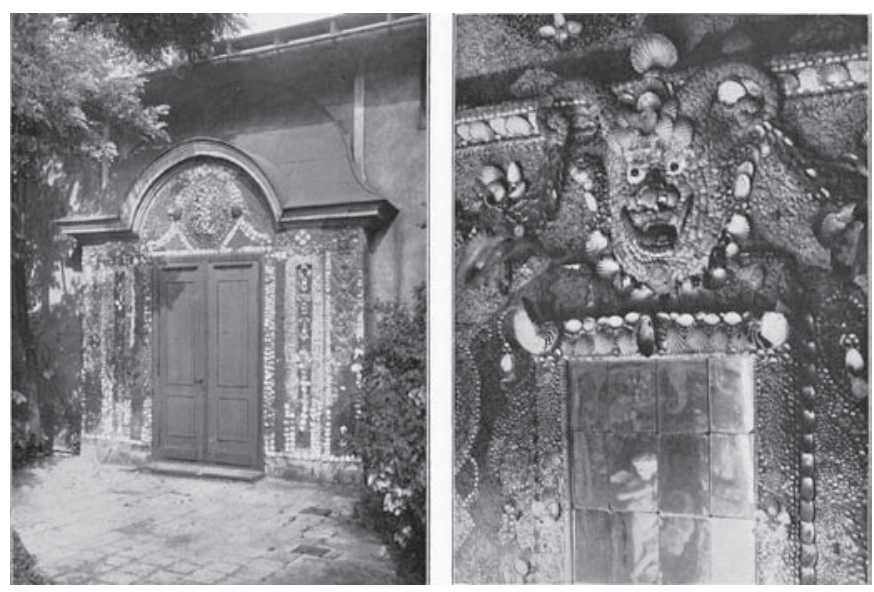

Рис. 13. Кёнигсберг. Сад Ф. Сатургуса. Грот: вход и фрагмент украшения интерьера (источник: [17]) 
ожидания, несмотря на то что накануне вечером они ужинали по-королевски во “дворе муз” Кайзерлинков» [15, S. 112].

Братья собирали произведения искусства и раритеты, организовали кабинет природы, хранителем которого в 1766 году был И. Кант [10, S. 110]. Именно здесь, рассматривая насекомое, заключённое в янтарь, философ произнёс известную фразу: «Если бы ты могло рассказать, что ты пережило в свою эпоху, мы многое могли бы узнать о жизни Земли». Позднее Кант писал в «Критике способности суждения» (1790), что «археологу природы предоставляется возможность по сохранившимся следам древнейших её катаклизмов в соответствии с известным ему или предполагаемым механизмом её воссоздать возникновение всего великого семейства творений» [19, с. 450]. А. Болотов восторгался коллекцией Сатургусов, расположенной в отдельном домике, обозначенном писателем как «маленькая кунст-камора или довольно полный натуральный кабинет». Будущий известный учёный записал: «Не мог я довольно налюбоваться зрением на множество редких и никогда мной не виданных вещей, а особенно на преогромное собрание разных руд, окаменелостей, камней, разных раковин, разных птичьих яиц, разных птичьих чучел, а паче всего на превеликое собрание янтарных штучек с находящимися внутри их мушками и козявочками, которыми навешен у него целый комод, и коих число до нескольких тысяч простирается» [5, с. 57].

Обширное собрание отметил астроном, математик и путешественник из Базеля, Иоганн Бернулли III, посетивший сад Сатургусов в 1778 году в компании И. Канта и других учёных Кёнигсберга. В третьем томе дневника путешественник посвятил Кабинету природы Сарториуса (как он называл Сатургуса) несколько восторженных страниц, отметив, что Кабинет обязательно «показывали всем благороднейшим путешествующим через Кёнигсберг как главную достопримечательность города» [7, S. 66]. В 1787 году собрание было выставлено на аукцион, после чего большая его часть стала основой коллекции Кёнигсбергского зоологического музея. Братья Сатургусы вскоре после окончания Семилетней войны, послужившей

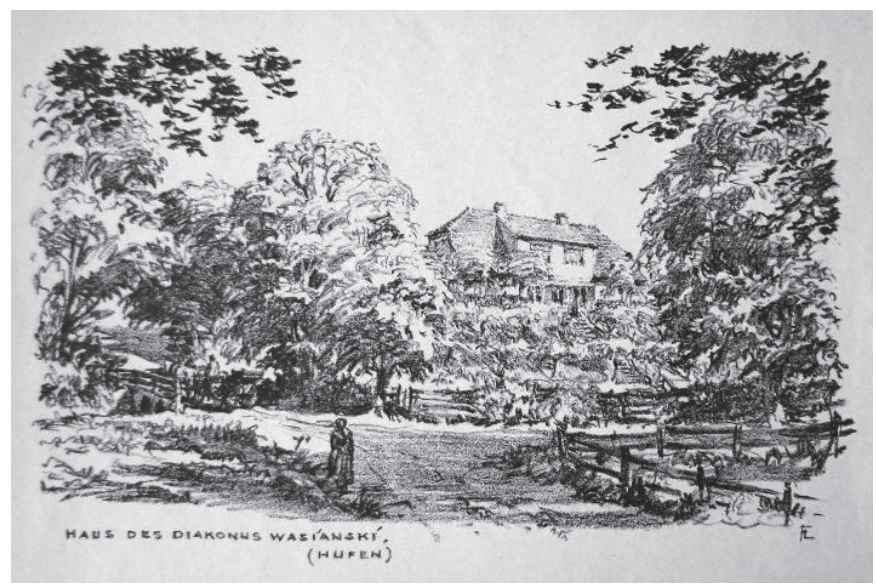

Рис. 14. Фридрих Ларс. Дом диакона Э. Васянского (Хуфен) (источник: Калининград, ММО, ед. хранения № 5361625) их обогащению за счёт поставок продовольствия для русской армии, оказались в трудном финансовом положении, в результате перепродаж дом и сад перешли в собственность юридического советника Самуэля Кунке (с 1788 года).

В 1795 году С. Кунке перестроил камерный рокайльный дом Ф. Сатургуса по проекту баумастера Августа Тредлера, превратил его в роскошный дворец в Цопфстиле ${ }^{14}$ и продолжил украшение парка $[15, \text { S. 108 }]^{15}$.

После 1831 года владельцем усадьбы стал Георг Карл Фридрих Цшок (1792-1848) [18, S. 249]. После смерти этого богатого купца во дворце жили три его незамужние сестры, завещавшие организовать приют для 27 девиц из обедневших купеческих семей, и в 1870 -е годы было построено специальное двухэтажное здание по проекту кёнигсбергского архитектора Диме [15, S. 129]. Согласно завещанию сестёр, парадные залы дворца должны были поддерживаться в постоянном порядке, а остальные помещения сдаваться внаём. Обитательниц приюта приглашали во дворец лишь два раза в год - для торжественной выдачи денежного вспомоществования. Тем не менее название «Цшокский приют» закрепилось именно за роскошной усадьбой, а не за скромным домом-богадельней.

На одной из литографий Ф. Ларс изобразил дом диакона Э.А.К. Васянского (1755-1831), известного благодаря написанной им книге «Иммануил Кант в последние годы жизни» [20]. В конце жизни философа диакон стал его незаменимым помощником: он относился к тем, кто, по выражению И. Канта, «мог бы дать дельный совет» [20, с. 40].

Загородный дом Э. Васянского стоял в предместье Хуфен, которое находилось за пределами городских укреплений и относилось к малозастроенному пространству гласиса перед бастионами Кёнигсберга (совр. проспект Мира, на этом месте сейчас находится Калининградский государственный колледж градостроительства БФУ им. И. Канта) (рис. 14). Ф. Ларс подчёркивает сельский облик поселения во второй половине XVIII века. Он создаёт своеобразное сценическое малозаселённое пространство с домом в глубине, одинокой женской фигурой слева и простенькой оградой из жердей справа на переднем плане.

$0 б$ этом доме диакон упоминал при описании совместной прогулки с И. Кантом поздним летом 1802 года, как о «небольшом месте отдыха перед Штайндамскими воротами ${ }^{16}$, домике, который я снял на несколько лет вместе с моим другом» [20, с. 73]. И. Кант к тому времени был серьёзно болен и боялся выехать из дома. «Я упаду в карете как тряпка», - говорил он $[20$, с. 72]. Э. Васянский писал, что в последний год жизни Канта «поездки, особенно к загородному домику, были для него

\footnotetext{
14 Термин Цопфстиль («стиль косички») практически не встречается в отечественном архитектуроведении, так как он имел в Европе локальное распространение и обозначал переходный этап между рококо и неоклассицизмом в период с 1760 по 1790 годы.

15 По мнению Ф. Гаузе, дворец перестроил «в вычурном стиле позднего немецкого рококо» очередной владелец дворца Г.К.Ф. Цшок [3, S. 145].

${ }^{16}$ Штайндамские ворота были снесены в ходе реконструкции Кёнигсберга в 1912 году.
} 
весьма полезны. Они вновь вызывали в нем те идеи прежних лет его жизни, которые его весьма ободряли. Упомянутый загородный домик находился на холме под высокими ольхами. Внизу в долине, протекал маленький ручей с водопадом, шум которого привлекал Канта» [20, с. 82]. Жилище диакона не отличалось архитектурными красотами, будучи типичной сельской усадьбой, которые во множестве встречались тогда в Восточной Пруссии, отличаясь лишь размерами. Но этот дом привнёс последние яркие впечатления в жизнь философа, возмечтавшего в старости о далёких путешествиях, но так и не решившегося покинуть родной край.

Литографии восточно-прусского архитектора Ф. Ларса посвящены городу, в котором практически безвыездно прожил знаменитый философ Иммануил Кант. Имя Канта служит своеобразным мостиком между двумя разными европейскими культурами - немецкой и российской. Комментарии показывают изменчивость городской ткани на протяжении последних трёх столетий, прошедших со дня рождения великого мыслителя, возвращая нас к историческим реалиям давнего Кёнигсберга - современного Калининграда.

\section{Лumepamypa}

1. Lahrs, Friedrich. Zum Bohnenmahl am 22. April 1936: Die Stadt Kants. Vorwort von Svetlana Kolbanewa. [Электронный ресурс] / Friedrich Lahrs // Официальный» сайт «Freunde Kants und Königsbergs e.V. Kant und Königsberg in Kaliningrad». - Режим доступа: https://www.freunde-kants. com/bohnenrede-lahrs (дата обращения 13.07.2020).

2. Кант, И. Критика чистого разума / Иммануил Кант; пер. с нем. Н. Лосского; сверен и отредактирован Ц.Г. Арзаканяном и М.И. Иткиным; примеч. Ц.Г. Арзаканяна. - М. : Эксмо, 2007. -736 c.

3. Гаузе, Ф. Кёнигсберг в Пруссии. История одного европейского города / Фритц Гаузе; Пер. с нем. В. Хердта и Н. Конрад. - Реклингхаузен : Биттер, 1994. - 316 с.

4. Faber, Karl. Die Haupt- und Residenz-Stadt Königsberg in Preussen. Das Werkwürdigste aus der Geschichte, Beschreibung und Chronik der Stadt / Karl Faber. - Königsberg: bei Gräfe und Unzer, 1840.

5. Болотов, А. Т. В Кёнигсберге. Из «Записок Андрея Тимофеевича Болотова, написанных самим им для своих потомков / А.Т. Болотов. - Калининград : Калининградское книжное издательство, 1990. - 191 с.

6. Atlantyda Północy. Dawne Prusy Wschodni w fotografii / Die Atlantis des Nordens. Das ehemalige Ostpreussen in der Fotografie. - Olstyn, 1993.

7. Bernoulli, J. Reisen durch Brandenburg, Pommern, Preussen, Curland, Russland und Pohlen in den Jahren 1777 und 1778. / Johann Bernoulli. Bd. 3. Reise von Danzig nach Königsberg, und von da nach Petersburg im Jahre 1778. Erste Abteilung. - Leipzig : bei Caspar Fritsch, 1779.

8. Исаков, И.Л. Описание Кёнигсберга русским консулом. 1785 г. / И.Л. Исаков // Кёнигсберг-Калининград. Иллюстри- рованный энциклопедический справочник /под общ. ред. Пржедомского А.С. - Калининград: Янтарный сказ, 2006. - С. 628-629.

9. Якшина, Д. Прогулки по Кёнигсбергу : [альбом] / Дина Якшина. - Калининград : Живём, 2010. - 255 с.

10. Jäger E., Schreiner $R$. Das alte Königsberg. Veduten aus 400 Jahren / Eckhard Jäger, Rupert Schreiner. - RegensburgGrünstadt : Garamond-Verlag, 1987.

11. Bötticher, A. Bau- und Kunstdenkmäler der Provinz Ostpreussen. Im Auftrag des Ostpreussischen ProvinzialLandtages / Adolf Bötticher. Heft VII. Königsberg. - Königsberg : Kommissionverlag von Bernh. Geichert, 1897.

12. Erhardt, T. Die Geschichte der Festung Königsberg Pr. 1257-1945. / Traugott Erhardt. - Frankfurt/Main-Würzburg : Gemeinschaftsverlag, 1960.

13. Салихова, Е.В. Хроники садов и парков (КёнигсбергКалининград) : Монография / Е.В. Салихова. - Калининград : Балтийский институт экономики и финансов, 2008. - 258 с.

14. Карамзин, Н.М. Письма русского путешественника : Избранные сочинения в 2 томах. Т. 1 [Электронный ресурс] / Н.M. Карамзин // LibreBook. - Режим доступа: https:// librebook.me/pisma_russkogo_puteshestvennika/vol1/1 (дата обращения 19.05.2020).

15. Mühlpfordt, Herbert Meinhard. Königsberger Leben im Rokoko. Bedeutende Zeitgenossen Kants / Herbert Meinhard Mühlpfordt. Siegen: im Selbstverlag der J.G. - Herder-Bibliothek Siegerland e.V., 1981. - S. 100.

16. Gause, F. Die Geschichte der Stadt Königsberg in Preußen / Fritz Gause. Bd. 1. - Köln; Wien : Böhlau, 1996.

17. Goldstein, Ludwig. Das Zschocksche Stift in Königsberg / Ludwig Goldstein // Neue Kunst in Altpreussen. Ostdeutsche Zeitschrift für Architektur, Malerei, Bildhauerkunst. Heft 5. Königsberg, 1911-1912. - S. 160-175.

18. Mühlpfordt, Herbert Meinhard. Königsberger Skulpturen und ihre Meister 1255-1945. / Herbert Meinhard Mühlpfordt. Würzburg : Holzner Verlag, 1970.

19. Кант, И. Критика способности суждения / Иммануил Кант; Сочинения в шести томах. Т. 5. - М. : Мысль, 1966. 565 c.

20. Васянский, Э.А.К. Иммануил Кант в последние годы жизни (Immanuel Kant in seinenletzten Lebensjahren) / Э.А.К. Васянский; Пер. с нем. А.И. Васкиневич. Предисловие И. Кузнецовой. - Калининград: Изд-во БФУ им. Канта, 2013. - 245 с.

21. Königsberg und Ostpreussen in historischen Ansichten und Plänen. - Leipzig : Staatsbibliothek zu Berlin. - Preussischer Kulturbesitz und Kochler\&Amelang GmbH, 2002.

22. Wagner, WulfD. Reise durch Königsberg und Ostpreussen in 1000 Bildern / Dietrich WulfWagner. - Königswinter : Mathias Lempertz GmbH, 2011.

23. Meier-Bremen Rudolf, Barfod Jörn. Frühe Ansichten Ost- und Westpreussens im Steindruck / Rudolf Meier-Bremen, Jörn Barfod. - Husum : Druck- und Verlagsgesellschaft mbH u. Co.KG, 2001. 


\section{References}

1. Lahrs Friedrich. Zum Bohnenmahl am 22. April 1936: Die Stadt Kants. Vorwort von Svetlana Kolbanewa. Freunde Kants und Königsbergs e.V. Kant und Königsberg in Kaliningrad. Access mode: https://www.freunde-kants.com/bohnenredelahrs (accessed 07.13.2020). (In Germ.)

2. Kant I. Kritika chistogo razuma [Critique of Pure Reason]. Moscow, EKSMO Publ., 2007, 736 p.

3. Gauze F. Kenigsberg v Prussii. Istoriya odnogo evropeiskogo goroda [Koenigsberg in Prussia. History of a European City]. Reklingkhauzen, Bitter Publ., 1994, 316 p. (In Russ.)

4. Faber Karl. Die Haupt- und Residenz-Stadt Königsberg in Preussen. Das Werkwürdigste aus der Geschichte, Beschreibung und Chronik der Stadt / Karl Faber. Königsbergб bei Gräfe und Unzer, 1840.

5. Bolotov A.T. V Kenigsberge. Iz «Zapisok Andreya Timofeevicha Bolotova, napisannykh samim im dlya svoikh potomkov [In Königsberg. From “Notes of Andrei Timofeevich Bolotov, written by him for his descendants]. Kaliningrad, Kaliningrad book publishing house, 1990, 191 p. (In Russ.)

6. Atlantyda Północy. Dawne Prusy Wschodni w fotografii. Die Atlantis des Nordens. Das ehemalige Ostpreussen in der Fotografie. Olstyn, 1993.

7. Bernoulli J. Reisen durch Brandenburg, Pommern, Preussen, Curland, Russland und Pohlen in den Jahren 1777 und 1778. Bd. 3. Reise von Danzig nach Königsberg, und von da nach Petersburg im Jahre 1778. Erste Abteilung. Leipzig, bei Caspar Fritsch, 1779. (In Germ.)

8. Isakov I.L. Opisanie Kenigsberga russkim konsulom. 1785 g. [Description of Koenigsberg by the Russian consul. 1785 ]. In: Przhedomskii A.S. (ed.) Kenigsberg-Kaliningrad. Illyustrirovannyi entsiklopedicheskii spravochnik [Koenigsberg-Kaliningrad. Illustrated encyclopedic reference]. Kaliningrad, Yantarnyi skaz Publ., 2006, pp. 628-629. (In Russ.)

9. Yakshina D. Progulki po Kenigsbergu [Walks in Koenigsberg] : al'bom. Kaliningrad, Zhivem Publ., 2010, 255 p. (In Russ.)

10. Jäger E., Schreiner R. Das alte Königsberg. Veduten aus 400 Jahren. Grünstadt, Garamond-Verlag, 1987. (In Germ.)

11. Bötticher A. Bau- und Kunstdenkmäler der Provinz Ostpreussen. Im Auftrag des Ostpreussischen Provinzial-
Landtages. Heft VII. Königsberg. Königsberg, Kommissionverlag von Bernh, Geichert, 1897. (In Germ.)

12. Erhardt, Traugott. Die Geschichte der Festung Königsberg Pr. 1257-1945. Frankfurt/Main-Würzburg, Gemeinschaftsverlag, 1960. (In Germ.)

13. Salikhova, E.V. Khroniki sadov i parkov (KenigsbergKaliningrad) [Chronicles of gardens and parks (KoenigsbergKaliningrad)]. Kaliningrad, Baltic Institute of Economics and Finance Publ., 2008, 258 p. (In Russ.)

14. Karamzin N.M. Pis'ma russkogo puteshestvennika [Letters of the Russian traveler], Selected works in 2 volumes, Vol 1. LibreBook. Access mode: https://librebook.me/pisma_russkogo_ puteshestvennika/vol1/1 (accessed 19.05.2020). (In Russ.)

15. Mühlpfordt, Herbert Meinhard. Königsberger Leben im Rokoko. Bedeutende Zeitgenossen Kants / Herbert Meinhard Mühlpfordt. Siegen: im Selbstverlag der J.G., Herder-Bibliothek Siegerland e.V., 1981, 100 s. (In Germ.)

16. Gause F. Die Geschichte der Stadt Königsberg in Preußen. Bd. 1. Köln; Wien, Böhlau, 1996. (In Germ.)

17. Goldstein Ludwig. Das Zschocksche Stift in Königsberg. Neue Kunst in Altpreussen. 0stdeutsche Zeitschrift für Architektur, Malerei, Bildhauerkunst. Heft 5. Königsberg, 1911-1912, Ss. 160-175. (In Germ.)

18. Mühlpfordt, Herbert Meinhard. Königsberger Skulpturen und ihre Meister 1255-1945. Würzburg, Holzner Verlag, 1970. (In Germ.)

19. Kant I. Kritika sposobnosti suzhdeniya [Critique of the ability to judge]. Immanuil Kant; Works in 6 volumes, Vol. 5. Moscow, Mysl' Publ., 1966. (In Russ.)

20. Vasyanskii E.A.K. Immanuil Kant v poslednie gody zhizni [Immanuel Kant in seinenletzten Lebensjahren]. Kaliningrad, IKBFU Publishing House, 2013. (In Russ.)

21. Königsberg und Ostpreussen in historischen Ansichten und Plänen. Leipzig, Staatsbibliothek zu Berlin. Preussischer Kulturbesitz und Kochler\&Amelang GmbH, 2002. (In Germ.)

22. Wagner Wulf D. Reise durch Königsberg und Ostpreussen in 1000 Bildern. Königswinter, Mathias Lempertz GmbH, 2011. (In Germ.)

23. Meier-Bremen Rudolf, Barfod Jörn. Frühe Ansichten Ost- und Westpreussens im Steindruck. Husum, Druck- und Verlagsgesellschaft mbH u. Co.KG, 2001. (In Germ.)

Белинцева Ирина Викторовна (Москва). Кандидат искусствоведения, доцент. Ведущий научный сотрудник Научно-исследовательского института теории и истории архитектуры и градостроительства (филиал ФГБУ «ЦНИИП Минстроя России») (111024, Москва, ул. Душинская, 9. НИИТИАГ). Эл. почта: belinceva@bk.ru.

Belintseva Irina V. (Moscow). PhD, docent. Leading researcher at the Research Institute of Theory and History of Architecture and Urban Planning (9 Dushinskaya st, Moscow, 111024. NIITIAG), branch of the Central Institute for Research and Design of the Ministry of Construction and Housing and Communal Services of the Russian Federation (TsNIIP). Email: belinceva@bk.ru. 